О.О.Шморгун, кандидат філософських наук, старший викладач Центру гуманітарної освіти НАН України

\title{
НАЦІОНАЛЬНА САМОСВІДОМІСТЬ ЯК ЕКЗИСТЕНЦІЙНИЙ ВИБІР: ЄВРОПЕЙСЬКИЙ ДОСВІД
}

У сучасному глобалізованому світі проблема національної ідентичності та філософські підходи до неї надзвичайно актуалізуються. Адже історичний досвід ХХ ст. незаперечно свідчить про те, що саме на тлі гострих кризових явищ у суспільстві зростає потреба в національній солідарності, що врешті-решт і створює особливий феномен позаекономічної патріотичної мотивації, без якої неможливий вихід із кризи і з якою пов'язане стрімке післявоєнне зростання у ряді країн Свропи і Далекого Сходу, що дістало назву «економічного дива».

На наше глибоке переконання, таке переосмислення не може відбутися без звернення до проблем індивідуального вибору, віднайдення людиною смислу власного буття, які у XX ст. у найбільш загостреній формі були поставлені представниками філософії екзистенціалізму. Втім, нам можуть заперечити: чи не є такі намагання дослідити питання національної самоідентичності в контексті екзистенціалізму методологічно безпідставними, чи не стоїть за ними спроба фактично нав'язати філософам-екзистенціалістам XX ст. предмет, до якого вони самі були байдужими? Адже знаменита сартрівська теза про те, що «сутність передує існуванню», на перший погляд, ніби якраз і спрямована на те, щоб максимально звільнити людину від відповідальності за все напередзадане, в тому числі й національну приналежність.

Причиною цих, на нашу думку, глибоко хибних стереотипів $\epsilon$ традиційна, на жаль, у нас неувага до культурно-історичних обставин виникнення тієї чи іншої філософської течії, розгляд іï ніби «у сухому залишку», відкинувши весь соціальний контекст як вторинний, що часто-густо обертається втратою надзвичайно важливих філософських смислів. 3 огляду на це, серед численних досліджень, присвячених екзистенціалізму, необхідно виділити статтю Е.Соловйова «Екзистенціалізм (історико-критичний нарис)», в 
якій він робить важливий висновок про вирішальну роль саме окупації Франції під час другої світової війни для остаточного становлення головних постулатів екзистенціалізму. Французький Рух Опору наповнив реальним смислом теза, згідно з якою людина завжди приречена робити вибір, навіть тоді, коли від нього ухиляється, що вона вільна від будь-якої «людської природи», якою вона могла б виправдати свої помилки, а, значить, свобода - це, передусім, відповідальність.

Е.Соловйов робить ще один нетрадиційний крок і залучає до свого дослідження також постать видатного французького письменника і мислителя-гуманіста А. де Сент-Екзюпері, якого він за досліджуваною проблематикою абсолютно виправдано відносить до основоположників французького екзистенціалізму, а його повість «Військовий льотчик» вважає ключовим першоджерелом, що допомагає зрозуміти вихідні положення та динаміку розвитку французької екзистенціальної філософії саме на тому вирішальному відтинку історії, коли вона перестала бути просто філософією і стала для нескореного народу Франції способом життя. Зокрема, пошуки та філігранний виклад тієї найвищої цінності, за яку варто віддати життя, навіть якщо ти заздалегідь приречений на поразку, яка, власне, і становить філософське підгрунтя «Військового льотчика». Цією цінністю для А. де Сент-Екзюпері є любов до Батьківщини: «Батьківщина - це не сукупність провінцій, звичаїв, предметів, які завжди може охопити мій розум. Батьківщина - це сутність... Тому, у кого нема почуття батьківщини, не можна прищепити його ніякою мовою. Створити в собі сутність, яку ти називаєш своєю, можна лише за допомогою дій. Сутність належить не до царини мови, а до царини дії... Найважливіша дія дістала назву. І ця назва жертва» [9; 305, 410-411].

Саме жертва об'єднала французів у боротьбі за національне визволення. Мабуть, з найбільшою переконливістю «межову ситуацію», в якій опинилася окупована Франція, окреслив Ж.-П.Сартр у статті «Республіка мовчання», написаній у 1944 році одразу після визволення. «Обставини нашої боротьби, часто нестерпні, поміщали нас у справжнє життя, без завіс та декорацій, занурювали в найнестерпніше та найболючіше становище, яке називають людським жеребом... Кожну секунду ми переживали смисл цієї короткої, але банальної фрази: «всі люди смертні». I вибір, який кожний 
робив для себе, був справжнім, тому що це був вибір перед лицем смерті, тому що ми завжди могли висловитися в дусі: «Краще вже смерть, ніж...»... Сама жорстокість супротивника штовхала нас до крайнощів, примушуючи задаватися питанням: «який Француз не вчинив би так само в тому чи іншому випадку» $[1,11-12],-$ пише французький філософ.

Але для французьких екзистенціалістів участь у Русі Опору не зводилась лише до вияву їхньої громадянської позиції: екзистенціалізм перетворився на свого роду філософію Опору та єднання перед загрозою окупації Батьківщини. «Коли прославлений Шарль Дюллен у червні 1943 року в окупованому Парижі показав «Мух», вистава була сприйнята, передусім, як зашифрована розповідь про Францію, поставлену на коліна і все ж таки не зломлену, як тираноборчий виклик та заклик до непокори, - пише С.Великовський. Уява, природно, схилялася до простої підстановки: Есгіф - це нацисти, що хазяйнують у підкореній країні, Клітемнестра - колабораціоністи Віші, що вступили у злочинний зв'язок з убивцями їх батьківщини, Орест - один із перших добровольців Опору, що подає іншим приклад свободи, Електра - французи, що мріють про повалення кривавого режиму, але коливаються і бояться справжньої справи. Все це, безсумнівно, було в «Мухах», і публіка ані трохи не помилилася, зрозумівши трагедію Сартра як театральний маніфест Опору...» [7, 12]. Так само, як і абсурдний герой «Міфу про Сізіфа» став для французів образом патріота, що знову і знову вступає у нерівний бій з окупантами, без надії на перемогу. Тут же в окупованому Парижі Ж.-П.Сартр пише ще одну основоположну для екзистенціалізму працю - філософський трактат «Буття і ніщо: нарис феноменологічної онтології», в якому «не зважаючи на абстрактну філософську мову та віддалені історичні приклади, уважний читач побачить... спонуку до дії проти існуючого порядку в період окупації» $[6,15]$, - зазначає В.Колядко.

Ще одним програмним документом екзистенціалізму того періоду є філософсько-полемічні «Листи до німецького друга» А.Камю. Сама їх назва - «Листи до німецького друга» - уже наводить на роздуми про те, що, очевидно, головною метою А.Камю було все ж таки не таврування нацизму та гітлеризму, що у 1943-1944 роках уже навряд чи було б на часі, а швидше спроба, нехай і жорсткополемічного, але все ж діалогу із представниками німецької інте- 
лектуальної еліти, причому, насамперед, з тією її частиною, яка на певному етапі повірила в ідеологію нацизму. Така постановка питання одразу ж відсилає нас до трагічної долі ще одного основоположника філософії екзистенціалізму - М.Гайдеггера, який чи не найбільше підходить на роль «німецького друга», на користь чого, зокрема, свідчить і те захоплення, яке його філософія викликала у французів, зокрема, у того ж Ж.-П.Сартра. Адже, на думку В.Бібіхіна, «його натхненне «Буття і ніщо»... було зліпком 3 «Буття і часу» аж до стилю та лексики, але служило самоутвердженню тієї самої емансипованої свідомості, із лабіринтів якої на простір вибирався німець (М.Гайдеггер. - О.Ш.)» $[8,14]$.

Однак є сторінки у біографії М. Гайдеггера, які становлять те, що нині прийнято називати «справою Гайдеггера», або його «гріхопадінням» (Н.Мотрошилова [5]). Це роки його симпатій до нацистського режиму i, зокрема, сумновідоме ректорство у Фрайбурзькому університеті з у 1933-1934 роках. В цілому ж біографів М.Гайдеггера можна розділити на два табори: «адвокатів» (їх переважна більшість), які стоять на позиціях того, що «помилку», «тимчасове затьмарення» мислителю можна пробачити з огляду на його величезну цінність для людства, та «обвинувачів» (їх меншість), які вважають, що «гріх нацизму» не можуть вибачити жодні пом'якшуючі обставини. Разом з тим «адвокатам» М.Гайдеггера стоїть на заваді так звана нерозкаяність німецького мислителя, його відмова публічно визнати свою неправоту після падіння нацистського режиму, навіть під загрозою репресій та заборони викладання. Отже, як це не парадоксально, вочевидь М.Гайдеггер відчував у чомусь за собою вагому правоту. В чому ж вона могла полягати? Відповідь на це питання почасти можуть дати «Листи...» А.Камю.

Так, зокрема, французький філософ підкреслює спільність духовно-світоглядних обставин, через які довелося пройти і Німеччині, і Франції у передвоєнний період і які фактично й породили особливий екзистенційний світогляд граничного відчаю, від якого один крок до масового схиляння перед тоталітарним диктатором, що здатен поселити в людях віру в можливість побудувати таке суспільство, життя в якому було б гідне їх та їхньої батьківщини [2; 3, 166-287]. А.Камю вражаюче чесний в своїх зізнаннях, коли вкладає в уста свого німецького опонента вельми критичні зауваження стосовно позиції французької інтелігенції напередодні другої 
світової війни, в тому числі й щодо зануреності більшої їі частини у смакування переживання відчаю, або відірвані від життя філософські спекуляції (і тим, й іншим дійсно грішив ранній французький екзистенціалізм, в тому числі певною мірою й сам автор «Листів...»).

В такій ситуації надзвичайно складно втримати націю від «звалювання» в моральний релятивізм, проти якого, до речі, довелося шукати протиотруту як німцям, так і французам. Ось що пише А.Камю, звертаючись до німців: «Ви вирішили, що за відсутності якої б то не було людської чи божественної моралі, єдині цінності це ті, які керують світом тварин, а саме: жорстокість і хитрість. Звідси ви вивели, що людина - ніщо і можна вбити іiі душу; що найбеззмістовніше завдання індивідуума полягає лише у демонстрації сили, а його мораль - у реалізмі завоювань. Правду кажучи, я, щуо думав, здавалося б, точно так само, не знаходив контраргументів, відчуваючи в собі хіба що жадібну жагу справедливості (курсив наш. - О.Ш.)... [4, 180]. Справді, і французам, і німцям доведеться докласти чималих зусиль, щоб навести промінь філософської думки на вищий смисл життя, затертий масовою свідомістю, яка завжди живе сьогоднішнім днем: таким смислом для екзистенціалістів стає людська солідарність у боротьбі, а об'єднує людей у братство нескорених біда Батьківщини.

I парадокс «нерозкаяння» М.Гайдеггера, на нашу думку, є якраз свідченням самостійності його філософських переконань, а не навіяності їх поточним політичним моментом. Адже і період симпатій до націонал-соціалізму (а він тривав не довше, ніж до 1935 року), і розчарування в ньому, жодним чином не могло означати для мислителя розриву з власною Батьківщиною. Навпаки, у філософії патріотизму він вбачав єдино можливу протиотруту і духовний порятунок від тих деструктивних процесів, які охопили як Німеччину, так і всю Європу. Чи не найбільш вичерпним джерелом в цьому контексті є лекція 3 дуже показовою назвою «Повернення на Батьківщину», прочитана М.Гайдеггером 6 червня 1943 року у Фрайбурзькому університеті 3 нагоди 100-річчя 3 дня смерті Ф.Гельдерліна. Сам вибір постаті видатного німецького поета-романтика теж далеко не випадковий. Адже, як свідчить Р.Сафранскі, автор одного з найвідоміших і найдокладніших життєписів М.Гайдеггера, німецький мислитель вважав Ф.Гельдерліна одним із своїх своєрідних «святих заступників» саме через те, що він, як ніхто інший, 
умів підносити у своїй творчості любов до Малої Батьківщини (Швабії, з якої походив і М.Гайдеггер) до рівня загальнолюдської філософії. Звісно ж, наполегливе звернення М.Гайдеггера до постаті Ф.Гельдерліна було продиктоване не лише особистими обставинами. Спадкоємність між філософськими перипетіями романтизму та течією екзистенціалізму (причетність М.Гайдеггера до якої, незважаючи навіть на відмежування від неї самого мислителя, все ж $\epsilon$ незаперечною) уже давно помічена як критиками, так і самими філософами-екзистенціалістами, які присвятили аналізу цього явища чимало місця [13].

Вчитаймося уважно в напівпоетичні рядки гайдеггерівського «Повернення на батьківщину»: «...Найвластивіше батьківщині «німецьке» заховано... Це... є таємний заклик до «інших» у вітчизні стати слухаючими, щоб почати вчитися пізнанню сутності батьківщини. Ці «інші» мають навчитися розмірковувати, обмірковуючи таємницю приховуваної близькості. Із розсудливих вийдуть неквапні довготривалої мужності, яка сама, у свою чергу, вчиться переживати нестачу бога, що все ще триває. Тільки розсудливі та довготривалі мужні є турботливими... Тоді є повернення на батьківщину... ие повернення на батьківщину є майбутня історична сутність німців (курсив наш. - О.Ш.)» $[11,45,55,57$.$] . Поетичну$ інтуїцію Ф.Гельдерліна М.Гайдеггер підносить на новий філософський рівень. Він прагне осмислити найглибші екзистенційні виміри любові до батьківщини як переживання особливої «приховуваної близькості», що за своєю духовною силою має долати потребу у надприродному (адже «бог помер»).

Невипадково й те, що «турбота» - фундаментальна структура, яка лежить в основі кожного прояву людської екзистенції, $є$ конститутивним елементом духовного переживання Батьківщини. «Оберігати таємницю приховуваної близькості до найрадіснішого та, оберігаючи, розгортати іï, - пише М.Гайдеггер, - ось у чому полягає турбота повернення на батьківщину» $[11,55]$. У свою чергу, основоположну категорію гайдеггерівської філософіï, «Dasein», на думку фахівців i, передусім, відомого сучасного гайдеггеріанця Ф.-В. фон Херрманна, можна пояснити через різні виміри турботи $[12,154]$. Зрештою, часто цитуючи загальновідомий вислів М.Гайдеггера про мову як дім істини Буття, є смисл замислитись над тим, що мислитель, передусім, мав на увазі саме національну 
мову. Отже, безпрецедентний за своїм задумом філософський проект М.Гайдеггера, якому він залишався вірним все своє життя, мав на меті створити не просто сучасну національну німецьку філософію, а, по суті, філософію екзистенційного націоналізму, яка, беручи витоки у потужних джерелах романтизму та «Весни народів», мала стати світоглядною альтернативою нацизму.

Про глибинну вкоріненість екзистенційно забарвлених національно-мобілізаційних рухів як у Франції (де вони виявилися у Русі Опору), так і в Німеччині (де спротив тоталітарному режиму мав латентний характер і ускладнювався тим, що справжні патріоти Німеччини мусили відроджувати ті самі ідеали служіння Батьківщині, які стали розмінною монетою у нацистській ідеологічній пропаганді) свідчить те стрімке взаємопроникнення екзистенційної філософії, яке розпочалося між цими двома країнами буквально у перші ж дні після завершення другої світової війни, причому французькі видання, запрошуючи М.Гайдеггера прокоментувати ситуацію в Німеччині, бачили в ньому ледь не речника всієї сучасної німецької філософії. Звісно, цьому сприяло і те, що частина Німеччини, де жив М.Гайдеггер, опинилася у французькій зоні окупації. Зокрема, на думку Н.Мотрошилової, це призвело до того, що нова німецька університетська адміністрація, побоюючись надто великої популярності мислителя у Франції, вдалася до більш серйозних заходів покарання, ніж це планувалося спочатку. Але в чому ж причина такого стрімкого зближення двох країн на екзистенційному грунті?

Якщо Ж.-П.Сартр у статті «Республіка мовчання» бідкається 3 приводу того, чи зможе Франція, ставши вільною, залишитись вірною тим екзистенційним ідеалам єднання, за які французи помирали під час окупації, то у зруйнованій вщент переможеній Німеччині «межова ситуація» якраз набувала граничного загострення. «Запропоноване Сартром формулювання «...Екзистенція передує «есенції», сутності» саме у зруйнованій Німеччині не могло не знайти відклику у світовідчутті тих, хто після катастрофи опинився серед руїн, але при цьому йому все ж таки вдалося врятуватись. Той, хто врятував свою екзистенцію, що б з ним не сталося, міг почати все заново. I, передусім, саме в цьому розумінні фраза Сартра... набула популярності в післявоєнній Німеччині», - пише Р.Сафранскі у книзі «Гайдеггер: німецький майстер та його час». Там же він згадує слова видатного німецького письменника, 
Е.Кьостнера, який, звільнившись 3 полону, повернувся у зруйнований Дрезден із відчуттям того, що більша частина речей втратила будь-яке значення: «В присмерковій Німеччині ти відчуваєш, що есенція - це і є екзистенція» $[8,470]$.

Про те, що основоположники екзистенціалізму М.Гайдеггер та Ж.-П.Сартр відчували глибинну спорідненість їхніх філософських концепцій, свідчить і реакція німецького мислителя на фундаментальну феноменологічну онтологію його французького колеги. У своїх особистих нотатках (що виключає будь-яку нещирість!) від 5 жовтня 1945 року М.Гайдеггер пише: «Вплив на Сартра має вирішальне значення; тільки тут «Буття і час» вперше збагнуте» [8, 462]. У листі до Ж.-П.Сартра від 28 жовтня 1945 року М.Гайдеггер знову висловлює захоплення французьким колегою: «Тут мені вперше зустрівся самостійний мислитель, який від самої основи осягнув ту сферу, зсередини якої я мислю. Ваша праця просякнута таким безпосереднім розумінням моєї філософії, якого мені ще ніде не доводилося зустрічати» [8, 461-462]. В листі лунає і надія на плідну співпрацю - М.Гайдеггер запрошує Ж.-П.Сартра разом «знову привести мислення до такої точки, починаючи 3 якої воно, як таке, буде сприйматися у якості основоположної події в історії та поставить сучасну людину у споконвічну причетність до буття», бо ж «необхідно з величезною серйозністю усвідомити мить, яку нині переживає світ, і виразити іiі в слові, перекривши суто партійні розбіжності, модні течіі, наукові напрямки...» [8, 462].

Втім, показово, що найбільше захоплення у М.Гайдеггера викликає саме той розділ «Буття і ніщо», де Ж.-П.Сартр осмислює проблему національності, яка, на думку французького філософа, тісно пов'язана 3 «комплексами знарядь», які людина засвоює від народження в тій місцевості, яка є для неї Малою Батьківщиною $[8,461]$. На думку Ж.-П.Сартра, не може бути не лише мови взагалі, а й французької мови взагалі, адже «реальність мови є національна мова, а реальність останньої - діалект, арго, говір і та ін.» [6, 520]. Так само неможливо бути і якимось абстрактним французом, можна бути лише, скажімо, савойцем, і саме ця «екзистенція савойця» накладає неповторний відбиток на все сприйняття життя людиною. «Таким чином, можна сказати, що реальність нашої приналежності до людства є наша національність, - розмірковує Ж.-П. Сартр, - отже, бути французом, наприклад, є тільки істина 
буття савойця. Але бути савойцем - це не просто жити у високих долинах Савойї; це значить, крім багатьох інших речей, взимку ходити на лижах, використовувати лижі як вид транспорту. I це значить, звичайно ж, ходити на лижах за французьким методом, а не за методом арлбергським чи норвезьким... Таким чином, французький лижник володіє «французькою швидкістю», щоб спуститися 3 лижних схилів, і ця швидкість відкриває йому особливий тип схилів, де б він не був, тобто швейцарські чи баварські Альпи, Телемарк чи Юра будуть пропонувати йому завжди сенс, складнощі, комплекс знарядь чи ворожість суто французькі» $[6,520]$. Ці думки дуже співзвучні $з$ міркуваннями М.Гайдеггера в «Поверненні на Батьківщину» про те, що на Батьківщину неможливо повернутись суто формально, просто змінивши територіальне розташування. Адже Батьківщина - це не щось зовнішне, це те, що, передусім, людина має відшукати в собі, саме тоді зможе відбутися таїнство радісного повернення до «приховуваної близькості» рідного, про яке пише М.Гайдеггер.

3 іншого боку, наголошує Ж.-П.Сартр, у проблемі національності ключову роль відіграє саме самоідентичність - добровільне прийняття людиною відповідальності за всі наслідки того, що вона француз, німець, єврей. Простіше кажучи, людина не перестане бути, наприклад, етнічним французом, навіть якщо з міркувань, скажімо, особистої безпеки публічно зречеться своєї національності, однак лише тоді, коли вона добровільно прийме на себе всю повноту відповідальності за те, що вона француз, аж до готовності ризикувати життям в ім'я Франції, вона стане французом по-справжньому, включить свою національність в свій «екзистенційний проект». Таким чином, Ж.-П.Сартр, на противагу консервативному підходу до нації як спільноти, пов'язаної, передусім, етнічним походженням, пропонує модерний проект національної самоідентичності як добровільно обраного екзистенційного зв'язку з моїми «ближніми», заснованого на спільності духовних потреб та боротьби 3 «людським жеребом», а не на расовій чи кровній спорідненості. Саме зрада цьому принципу і призвела врешті-решт Німеччину до тоталітарної катастрофи, адже німці, що палили книги Г.Гейне, Е.Ремарка, Дж.Лондона, 3.Фройда, А.Ейнштейна, в буквальному розумінні перестали бути німцями в модерному розумінні цього слова, відкинули самі себе до первісних часів 3 їх міфологічною 
вірою в те, що представник іншого роду, іншого племені - це взагалі не людина. Однак і шлях Франції виявися тернистим: від післявоєнного національно-культурного піднесення та «економічного дива» до знаменитого афоризму Шарля де Голля перед виходом у відставку в 1969 році: «французи перестали хотіти бути французами»...

На жаль, співпраці двох видатних мислителів XX ст. М.Гайдеггера та Ж.-П.Сартра так і не судилося здійснитися. Їхні шляхи розійшлись. Однак вичерпний аналіз подальшого розвитку філософії екзистенціалізму виходить за межі завдань даної статті. Втім, виявилось, що екзистенційна методологія цілком придатна для розробки проблем національної ідентичності, оскільки сама філософія екзистенціалізму формувалася у тісному зв'язку з ними. Більше того, саме гостра екзистенційна «межова ситуація», що загрожує втратою національної ідентичності, загострює потребу в ній до рівня смисложиттєвого екзистенційного вибору. Наразі ж Україна, а значною мірою і Європа, перебувають саме у такій трагічній «межовій ситуації», виходом із якої може стати тільки переосмислення проблеми національної ідентичності як життєво важливої цінності, яку кожен обирає добровільно і за яку несе всю повноту відповідальності.

\section{ЛIТЕРАТУРА}

1. Sartre J.-P. Situations, III. Lendemains de guerre. - Éditions Gallimard, 1949, renouvelé en 1976. $-312 \mathrm{p}$.

2. Галкин А.A. Германский фашизм. - М., 1989. - 352 с.

3. Данилов С.Ю. Правовые демократические государства: очерки истории. Выпуск 1. - М., 1999. - 291 с.

4. Камю А. Письма к немецкому другу // Камю А. Сочинения в пяти томах. Харьков, 1997. - Т. 2. -527 с.

5. Мотрошилова Н.В. Драма жизни, идей и грехопадения Мартина Хайдеггера // Квинтэссенция: философский альманах, 1991. - М., 1992. C. $158-236$.

6. Сартр Ж.-П. Бытие и ничто: Опыт феноменологической онтологии. M., 2000. -639 c.

7. Сартр Ж.-П. Пьесы. - М., 1999. - 560 с.

8. Сафрански Р. Хайдеггер: германский мастер и его время. - М., 2005. $-614 \mathrm{c}$

9. Сент-Экзюпери А. де. Военный летчик // Сент-Экзюпери А. де. Сочи- 
нения. - М., 1964. - С.965.

10. Соловьев Э.Ю. Экзистенциализм (историко-критический очерк) // Соловьев Э. Прошлое толкует нас: (Очерки по истории философии и культуры). - М., 1991. - С.286-345.

11. Хайдеггер М. Разъяснения к поэзии Гёльдерлина. - СПб., 2003. - 320 с.

12. Херрманн Ф.-В. фон. Понятие феноменологии у Хайдеггера и Гуссерля. - Минск, 2000. - 192 с.

13. Шморгун Олександра. Драма людського буття: від відчаю до свободи. Леся Українка і Жан-Поль Сартр // Філософська думка. - №2010. № 4. - C.86-102.

Шморгун О.О. Національна самосвідомість як екзистенціийний вибір: європейський досвід.

У статті досліджується роль національної ідентичності та самоідентичності у становленні та розвитку екзистенціалізму як провідної філософської течії ХX ст. Розглядаються філософські аспекти процесів європейського націотворення у XX ст., зокрема, філософування М.Гайдеггера як спроба творення новітнього німецького екзистенційного націоналізму, що міг би стати духовною альтернативою нацистській ідеології, у його тісному світоглядному переплетінні з екзистенційною філософією, породженою французьким Рухом Опору.

Ключові слова: національна ідентичність, екзистенціалізм, М.Гайдеггер, Ж.-П.Сартр, А.Камю, А. де Сент-Екзюпері.

Шморгун А.А. Национальное самосознание как экзистенциальный выбор: европейский опьт.

В статье исследуется роль национальной идентичности и самоидентичности в становлении и развитии экзистенциализма как ведущего течения философской мысли ХХ ст. Рассматриваются философские аспекты процессов европейского нациогенеза в ХХ в. и, в частности, философствования М.Гайдеггера, как попытки создания новейшего немецкого экзистенциального национализма, который мог бы стать духовной альтернативой нацистской идеологии, в его тесном мировоззренческом переплетении с экзистенциальной философией, порожденной французским Сопротивлением.

Ключевые слова: национальная идентичность, экзистенциализм, М.Гайдеггер, Ж.-П.Сартр, А.Камю, А. де Сент-Экзюпери.

Shmorgun O. National identity as an existential choice: the European experience.

In the article the role of problem of national identity and self-identity in formation and development of existentialism as a leading philosophical flow 
of XX century is examined. Also the article considers the philosophical dimension of the processes of European national creation in the twentieth century and, in particular, philosophizing of $\mathrm{M}$. Heidegger as attempts to create the latest German existential nationalism, which could become a spiritual alternative to the Nazi ideology, in its close ideological combining with the existential philosophy generated by the French Resistance.

Key words: national identity, existentialism, M.Heidegger, J.-P. Sartre, A.Camus, A. de Saint-Exupéry. 